\title{
Seroprevalence of IgM Antibodies to Dengue Fever Virus among Patients Presenting with Symptoms of Fever in Some Hospitals in Kaduna State, Nigeria
}

\author{
O. A. Bello ${ }^{1 *}$, M. Aminu ${ }^{1}$, E. D. Jatau ${ }^{1}$ \\ ${ }^{1}$ Department of Microbiology, Ahmadu Bello University, Zaria, Kaduna State, Nigeria
}

\begin{abstract}
Dengue fever is a viral infection that has become a major public health concern. The research was aimed at determining the seroprevalence of dengue fever virus by screening for IgM antibodies against the virus. A cross sectional study was carried out in three selected Local government Areas (Zaria, Kafanchan, and Birnin-Gwari Local) of the three senatorial district of Kaduna state, Nigeria from October to December 2014. A total of 366 patients presenting with symptoms of fever were recruited and about $5 \mathrm{mls}$ of whole blood was obtained after obtaining consent. Presence of IgM antibodies to dengue fever virus was determined using Enzyme Linked Immunosorbent Assay (ELISA). A prevalence of 51.9\% was obtained for IgM to Dengue fever Virus. There was a significant difference in the prevalence of the antibodies among the three LGAs studied with Kafanchan having the highest prevalence of 72.95\% (89/122). Females had a higher prevalence of $57.21 \%$. In terms of occupation, there was a significant difference in the prevalence obtained with farmers having the highest prevalence of $60.00 \%$. There was no significant difference between age and dengue fever. However, participants who were 71years and above had the highest prevalence (85.71\%: 6/7) and the lowest was found among participants in age group 51-60years old (30.43\%: 7/23). This study showed a high prevalence of IgM to Dengue fever virus indicating the circulation of this virus mostly among female patients with symptoms of fever in Kaduna State. Febrile patients should be tested for dengue fever virus to avoid likely misdiagnosis of dengue fever and treatment as malaria.
\end{abstract}

Keywords: Dengue fever, IgM, Fever Patients, Kaduna state, Nigeria.

\section{Introduction}

Dengue fever virus (DENV), a flavivirus, is the cause of a mosquito-borne viral infection that in recent decades has become a major international public health concern [1] Dengue fever virus is maintained in nature in cycles that involve preferred blood-sucking vectors and vertebrate hosts [2]. The virus is maintained in the forests of Southeast Asia and Africa by transmission from female Aedes mosquitoes of species other than Aedes aegypti to her offspring and to lower primates [2].

Dengue is associated with clinical manifestations such as fever, arthralgia, myalgia, rash, headache and sometimes thrombocytopenia. The virus seems to have no detrimental effect on the mosquito, which remains infected for life. Dengue fever is a zoonosis maintained in nature by mosquitoes transmitting virus between non-human primate species, most of which develop clinically inapparent infection $[3,4]$.

Due to poor disease surveillance and lack of reporting, the true incidence and impact of dengue in Nigeria is unknown. Thus data on the burden of the disease and associated economic impact is lacking [5]. Dengue, a mosquito-borne viral infection is regarded as a major public health problem globally. The two main clinical manifestations namely dengue haemorrahagic fever (DHF) and dengue shock syndrome (DSS) are responsible for exacting heavy morbidity and mortality every year and continues to be serious public health problem [6]. Due to poor disease surveillance and lack of reporting, the true incidence and impact of dengue in Nigeria is unknown. Thus data on the burden of the disease and associated economic impact is lacking [5]. In addition, due to the significant endemicity of malaria in Nigeria, majority (>70\%) of febrile illnesses, including dengue, are likely to be misdiagnosed and treated as malaria [5]. Understanding risk factors to infection is important for public health control programs. The evaluation of male-female difference in infection rates for instance has been difficult to discern [7-9]. Dengue surveillance in Nigeria is affected by the lack of routine laboratory diagnosis. Laboratory diagnosis of dengue may include culture, polymerase chain reaction (PCR), and serological assays [10]. A study in Nigeria determined the prevalence of flavivirus infections among 1,816 children and adults from urban and rural areas in samples obtained mainly during the early 1970s [11]. A prevalence of $30.8 \%$ was reported by Faneye et al. [12], 17.7\% by Srinivas et al. [13], 17.2\% in Ogbomoso by Oladipo etbal. [14] and $0.6 \%$ reported by Baba et al. [15]. The results of these studies emphasize the importance of surveying dengue fever virus. Hence this study aimed at screening for IgM antibodies specific to Dengue fever virus among patients presenting with symptoms of fever in some hospitals in Kaduna State, Nigeria.

\section{Materials and Methods}

\section{Study Design}

A cross sectional study was carried out across the three senatorial zones in Kaduna state, Nigeria. Purposive sampling was used to select a LGA and a hospital in each senatorial zone. 


\section{International Journal of Science and Research (IJSR) \\ ISSN (Online): 2319-7064 \\ Index Copernicus Value (2013): 6.14 | Impact Factor (2014): 5.611}

\section{Study Area and Population}

Kaduna State is in the center of Northern Nigeria and more than $1000 \mathrm{~km}$ from the Atlantic Ocean [16]. It is located on a Latitude of $11^{0} 12^{`} \mathrm{~N}$ and a Longitude of $07^{0} 37^{`} \mathrm{E}$. The State is the successor of the old Northern Region of Nigeria, which had its capital at Kaduna. In 1967 this was divided into Six (6), one of which was the North Central State, which was divided to Kaduna and Katsina State in 1987. Samples were collected from three different hospitals covering the three senatorial districts. The study population comprised of both male and female febrile patients all of ages. In addition to fever, patients having severe headache, neck and back pain possibly accompanied by vomiting, abdominal pain, diarrhoea were included in the study. The sample size was calculated using the formula of Sarmukaddam and Gerald [17] and a prevalence estimated by Faneye et al. [12] for Dengue fever in a previous study.

\section{Inclusion and Exclusion Criteria}

The inclusion criteria included all consented patients of all ages presenting with symptoms of fever $\left(>37.8^{0} \mathrm{C}\right)$ in the three selected hospitals for this study. For children; children whose parent(s) gave consent and were presenting with fever. Exclusion criteria included all patients who did not present with symptoms of fever and who did not give consent.

\section{Ethical Approval}

Ethical approval was obtained from the State Ministry of Health and Ethics Committee of the selected hospitals before the study was conducted.

\section{Sample Collection and Storage}

About $5 \mathrm{mls}$ of whole blood was collected by venipuncture by a nurse into a sterile plain bottle and the blood was allowed to clot. The blood was then spun at $1500 \mathrm{rpm}$ for 5 minutes. The serum was aspirated with sterile pipette tips into clean vials and stored at $20^{\circ} \mathrm{C}$ until analyzed.

\section{Detection of IgM Antibodies}

The IgM to Dengue fever virus was detected in the serum using ELISA kits (Diagnostics Automation/Cortez Diagnostics Inc. Calabasas, CA 91302, USA) according to the manufacturer's procedure. The wash Buffer cap was removed and contents of bottle were added to $475 \mathrm{ml}$ of reagent grade water. Diluted wash buffer was placed into a squeeze bottle with a narrow tip opening. A 1:40 dilution of patient's sera was made using the dilution buffer (e.g. $10 \mu \mathrm{l}$ sera and $390 \mu \mathrm{l}$ dilution buffer). The wells were broken off (two for controls) plus number of samples and placed in a strip holder. $100 \mu \mathrm{l}$ of negative control was added to well \#1 and $100 \mu$ l of positive control was added to well \#2 and $100 \mu \mathrm{l}$ of the diluted (1:40) test samples to the remaining wells. Incubation was done for 10 minutes at room temperature. The contents were shaken and washed 3 times with the diluted wash buffer and 2 drops of enzyme conjugate was added to each well. The plate was incubated at room temperature for 10 minutes. The contents was shaken out and washed three times with wash buffer and slapped against paper towels to remove all liquid. Two drops of chromogen was added to every well and incubated at room temperature for 5 minutes. Two (2) drops of stop solution was added and mixed by tapping the strip holder and the reading was taken.

\section{Interpretation of Results}

Samples that were positive were recorded to have values $>$ 1.0 OD or +++ or $>$ while negative samples were recorded to have values $0.0-0.3$ OD units, or zero colour.

\section{Analysis of Data}

The data generated from the questionnaire for this study and the result from the analysis was analyzed using SPSS version 15.0 for windows software. Simple frequencies and tables were generated, while categorized variables were compared using chi square test. A p-value less or equal to 0.05 was considered as statistically significant at 95\% confidence interval.

\section{Results}

\section{Study Population}

Data obtained using questionnaire was analyzed according to socio-demography of the participants and the results is presented in Table 1. A total of 179 (48.9\%) of the participants were male while 187 (51.1\%) were females. Majority of the participants were between 21-30 years old while the least were those above 71 years old. Based on occupation, the unemployed participants were more (168/366: 45.9\%) while the businessmen were fewer (39/366: 10.6\%).

Result of some risk factors concerning the study population is shown in Table 2. Majority of the participants lived in household with 1-10 people (247/366: $67.5 \%$ ) while participants living in a household of more 21 were fewer (20/366: $5.46 \%$ ). Most of the participants carried out environmental exercises 1-3 times a month (148/366: 40.43\%) while fewer numbers (13/366: 3.55\%) carried out environmental exercises 1-7 times a month. Based on history of travel, participants that did not leave their place of residents were more (324/366: 88.52\%) compared to those that travelled out (42/366: 13/366).

\section{Analysis of the ELISA Results}

Out of the 366 subjects whose sera were tested for Dengue IgM antibody using ELISA, 51.9\% (190/366) were positive and $48.1 \%(176 / 190)$ were negative $\left(\chi^{2}=0.536\right.$, $\mathrm{df}=1, \mathrm{p}=0.464$ ) (Figure 1 ). Antibodies to the virus was detected with the highest prevalence (72.95\%: 89/122) in Kafanchan and with the lowest prevalence (34.42\%: 42/122) in Birnin Gwari (Table 3). There was a statistically significant difference in the distribution of IgM to Dengue fever virus in the study area $\left(\chi^{2}=37.191\right.$, $\mathrm{df}=2, \mathrm{p}=0.000$ ). Based on demographic factors, a total of 


\section{International Journal of Science and Research (IJSR) \\ ISSN (Online): 2319-7064 \\ Index Copernicus Value (2013): 6.14 | Impact Factor (2014): 5.611}

107 of the female participants were positive for Dengue IgM giving a prevalence of $57.21 \%$ while 83 of the male participants were positive giving a prevalence of $46.36 \%$. The difference observed in the prevalence between male and females was statistically significant $\left(\chi^{2}=4.313\right.$, df $=1$, $\mathrm{p}=0.038$ ) and a C.I of 0.646(0.428-0.977).

The result was analyzed according to age and the highest prevalence (85.71\%: 6/7) was found among participants who were 71years and above and the lowest (30.43\%: $7 / 23$ ) was found among participants in age group 5160years old. There was no statistically significant difference between age and the presence of IgM to Dengue fever $\left(\chi^{2}=15.773\right.$, df $\left.=9, \mathrm{p}=0.072\right)$. In terms of occupation, IgM to Dengue fever was detected with the highest prevalence of $60.00 \%$ (39/65) among farmers while the lowest prevalence of $50.00 \%$ (84/168) was recorded among the unemployed. There was no statistically significant difference between occupation and the presence of IgM to Dengue fever $\left(\chi^{2}=3.546\right.$; $\mathrm{df}=6$, $\mathrm{p}=0.738$ ) in Table 4 .

Table 1: Frequency of some demographic factors of the study population

\begin{tabular}{|c|c|c|}
\hline Variable & Frequency & Percentage (\%) \\
\hline Sex & & \\
\hline Male & 179 & 48.90 \\
\hline Female & 187 & 51.09 \\
\hline Age & & \\
\hline $1-10$ & 51 & 13.93 \\
\hline $11-20$ & 81 & 22.13 \\
\hline $21-30$ & 89 & 24.31 \\
\hline $31-40$ & 55 & 15.02 \\
\hline $41-50$ & 45 & 12.29 \\
\hline $51-60$ & 23 & 6.28 \\
\hline $61-70$ & 15 & 4.09 \\
\hline $71>$ Above & 7 & 1.91 \\
\hline Occupation & & \\
\hline Unemployed & 168 & 45.90 \\
\hline Civil Servant & 41 & 11.20 \\
\hline Businessmen & 39 & 10.65 \\
\hline Farmers & 65 & 17.75 \\
\hline Others & 53 & 14.48 \\
\hline
\end{tabular}

Table 2: Frequency of some risk factors of the study population

\begin{tabular}{|c|c|c|}
\hline Variable & Frequency & Percentage (\%) \\
\hline \multicolumn{2}{|c|}{ Number of People in Household } \\
\hline $1-10$ & 247 & 67.48 \\
\hline $21-20$ & 99 & 27.04 \\
\hline$\geq$ & 20 & 5.46 \\
\hline Environmental Sanitation & & \\
\hline Not at all & 14 & 3.82 \\
\hline $1-3$ & 148 & 40.43 \\
\hline $4-6$ & 93 & 25.40 \\
\hline $7-9$ & 13 & 3.55 \\
\hline Everyday & 50 & 13.66 \\
\hline Unspecified & 48 & 13.11 \\
\hline History of Travel & & \\
\hline Did not Travelled & 324 & 88.52 \\
\hline Travelled & 42 & 11.47 \\
\hline
\end{tabular}

195

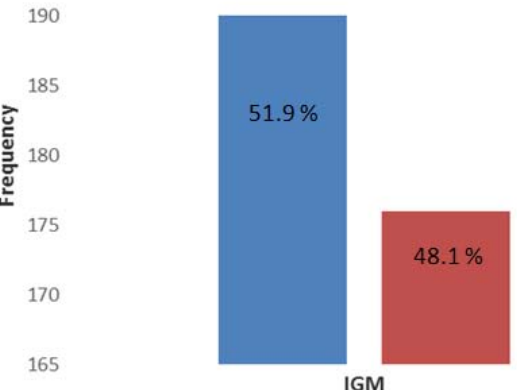

Figure 1: Seroprevalence of IgM to Dengue fever virus among patients attending some hospitals in Kaduna State, Nigeria

Table 3: Seroprevalence of Dengue fever virus according to location among patients attending some hospitals in Kaduna State, Nigeria

\begin{tabular}{|c|c|c|c|c|}
\hline $\begin{array}{c}\text { Location } \\
(\text { LGA) }\end{array}$ & Total & $\begin{array}{c}\text { Number } \\
\text { Positive (\%) }\end{array}$ & $\begin{array}{c}\text { Number } \\
\text { Negative (\%) }\end{array}$ & $\begin{array}{c}P \\
\text { Value }\end{array}$ \\
\hline Kafanchan & 122 & $89(72.9)$ & $33(27.04)$ & 0.000 \\
\hline $\begin{array}{c}\text { Birnin } \\
\text { Gwari }\end{array}$ & 122 & $42(34.42)$ & $80(65.57)$ & \\
\hline Zaria & 122 & $59(48.36)$ & $63(51.63)$ & \\
\hline Total & $\mathbf{3 6 6}$ & $\mathbf{1 9 0 ( 5 1 . 9 )}$ & $\mathbf{1 7 6 ( 4 8 . 1 )}$ & \\
\hline
\end{tabular}




\section{International Journal of Science and Research (IJSR) ISSN (Online): 2319-7064}

Index Copernicus Value (2013): 6.14 | Impact Factor (2014): 5.611

Table 4: Seroprevalence of Dengue fever virus according to demographic characteristics among patients attending some hospitals in Kaduna State, Nigeria

\begin{tabular}{|c|c|c|c|c|}
\hline Variable & Number Analyzed & Number Positive (\%) & Number Negative (\%) & $P$ Value \\
\hline \multicolumn{5}{|l|}{ Sex } \\
\hline Male & 179 & $83(46.36)$ & 96(53.63) & 0.038 \\
\hline Female & 187 & $107(57.21)$ & $80(42.78)$ & \\
\hline \multicolumn{5}{|l|}{ Age } \\
\hline $1-10$ & 51 & $25(57.21)$ & $26(50.98)$ & 0.072 \\
\hline $11-20$ & 81 & $36(44.44)$ & 45(55.55) & \\
\hline $21-30$ & 89 & $57(64.00)$ & $32(35.95)$ & \\
\hline $31-40$ & 55 & $30(54.54)$ & $25(45.45)$ & \\
\hline $41-50$ & 45 & $21(46.66)$ & 24(53.33) & \\
\hline $51-60$ & 23 & $7(30.43)$ & $16(69.56)$ & \\
\hline $61-70$ & 15 & $8(53.33)$ & $7(46.66)$ & \\
\hline 71> Above & 7 & $6(85.71)$ & $1(14.28)$ & \\
\hline \multicolumn{5}{|l|}{ Occupation } \\
\hline Unemployed & 168 & $84(50.00)$ & $84(50.00)$ & 0.738 \\
\hline Civil Servant & 41 & $22(53.65)$ & 19(46.34) & \\
\hline Businessman & 39 & $20(51.28)$ & 19(48.71) & \\
\hline Farmer & 65 & $39(60.00)$ & $26(40.00)$ & \\
\hline Others & 53 & $27(50.94)$ & $26(49.05)$ & \\
\hline
\end{tabular}

\section{Discussion}

This study has revealed that $51.90 \%$ of patients attending three selected hospitals in Kaduna state Nigeria have been exposed to Dengue fever virus as indicated by the presence of IgM antibodies in their serum. The $51.9 \%$ prevalence obtained in this study is higher than the report of previous studies in Nigeria. A prevalence of $30.8 \%$ was reported by Faneye et al. [12], $17.7 \%$ by Srinivas et al. [13], 17.2\% in Ogbomoso by Oladipo et al. [14] and $0.6 \%$ reported by Baba et al. [15].

The prevalence is also higher than that reported in a study carried out in Singapore [18] where a prevalence of $2.65 \%$ was obtained. Having IgM in the blood of these patients indicates recent infection of the virus and the high frequency of bite by the vector mosquito. From this study, it was observed that sex was a predisposing factor with more females being infected than males. This observation contrasts that of Oladipo (2014) who reported a higher prevalence in males than females. It also contrast the observation of Brown et al. (2009) who reported an association between sex and Dengue fever where all the males where positive and none of the females was. In some previous study, higher prevalence of dengue infection was also noted among males than females [19, 20 21]. These differences in prevalence in sex could be attributed to the differences in sample size collected for the studies, (where more samples were collected from females), the occupation of participants in the studies and exposure to the vector of the virus. Furthermore in the study areas, more women were engaged in farming and some outdoor activities such as going to the stream to fetch water and market. The study was conducted during the dry season when the agricultural activities are minimal. During this period more women were engaged in outdoor activities such as going to the stream to fetch water and the market hence these women could have passed through forested areas to get to the market.
From this study, demographic factors such as age and occupation were not found to have any association with dengue fever virus ( $p>0.005)$. Even though there was no association between age and dengue fever, the highest prevalence of IgM to Dengue fever was obtained among patients older than 71years while the lowest was among patients between 51-60 years old. This observation is similar to that reported by Baba et al. (2010) where no association between dengue and age was observed. Despite lack of association between occupation and dengue fever, the unemployed had a lower risk to dengue fever infection than farmers who are more exposed to the virus. This agrees with Oladele (2014) who reported a higher prevalence of Dengue virus among farmers. These results show that farmers are predisposed to the virus due to farming activities.

The higher prevalence obtained in this study when compared with other studies could be due to the difference in geographical location and the time of the year the studies were carried out. The present study was carried out during the dry season between October and December 2014. Although no rainfall occurred during this period, the poor drainage system and waste disposal in this area results in stagnant water bodies and water collected in waste metal containers and vehicle tyres which breeds Aedes spp mosquito which is the vector of virus. This high prevalence reported in this study is of significant public health concern. This also adds to existing knowledge and data on the prevalence of dengue fever infection in Kaduna, Nigeria. There should be proper and early detection of the virus which is essential for adequate management. Furthermore patients should be thoroughly screened for dengue fever virus alongside malaria/typhoid in order to maintain effective treatment. The populace should be enlightened on the activities that predispose them to dengue fever infection and also on the need to visit the hospitals as soon as they observe some of the symptoms associated with the virus. Further studies of this virus are needed to establish the trend of infection among age, sex, occupation and more importantly the seasonal variation of the virus. 


\section{International Journal of Science and Research (IJSR) \\ ISSN (Online): 2319-7064 \\ Index Copernicus Value (2013): 6.14 | Impact Factor (2014): 5.611}

\section{Conclusion}

This study has shown a seroprevalence of dengue fever virus to be $51.9 \%$. This result suggests that dengue fever virus is circulating among patients who present with symptoms of fever in Kaduna State. The prevalence of IgM to dengue fever virus was highest $(72.9 \%)$ in Kafanchan suggesting a high presence of dengue fever in the area. There was higher prevalence of Dengue fever among females revealing that some activities predispose women to the virus. Occupation and age were not associated with dengue fever virus infection.

\section{Acknowledgements}

The authors wish to acknowledge the Department of Microbiology Ahmadu Bello University, Zaria, Kaduna State and all the participants, nurses and laboratory personnel who made this study a reality.

\section{Competing Interests}

Authors have declared that no competing interests exist.

\section{References}

[1] WHO. (1997) Dengue Haemorrhagic Fever: Diagnosis, Treatment, Prevention and Control. Second Edition, Geneva. World Health Organisation, p. 12-23.

[2] Gubler, D.J., (2010). Dengue Viruses. In: Desk Encyclopedia of Human and Medical Virology, Mahy, B.W.J., and Van Regenmortel, M.H.V (Eds.), Academic Press, Oxford, ISBN -10: 0123785596, pp: 372-82.

[3] Dawurung, J.S., Baba, M.M., Stephen, G., Jonas, S.C and Bukbuk, D.N (2010). Serological evidence of acute Dengue virus infection among febrile patients attending, Plateau State specialist hospital Jos, Nigeria. Report and Opinion, 2: 71-76.

[4] Baba, M.M., and Talle, M. (2011). The effect of climate on Dengue virus infection in Nigeria. New York Science Journal, 4: 28-33.

[5] Ayukekbong, J.A. (2014). Dengue Virus in Nigeria: Current Status and Future Perspective. British Journal of Virology, 1(3): 106-111.

[6] Gubler, D. J. (1998) .Dengue and dengue haemorrhagic fever. Journal of Clinical Microbiology, 11: 480-496.

[7] Goh, K. T., Ng, S.K., Chan, S. J., Lim, and Chua, E.C. (1987). Epidemiological aspects of an outbreak of dengue fever/dengue haemorrhagic fever in Singapore. The Southeast Asian Journal of Tropical Medicine and Public Health, 18: 295-302.

[8] Agarwal, R., Kapoor, S., Nagar, R., Misra, R., Tandon, R., Mathur, A., Misra, A.K., Srivastava, K.L., and. Chaturvedi. U. C. (1999). A clinical study of the patients with dengue hemorrhagic fever during the epidemic of 1996 at Lucknow, India. The Southeast Asian Journal of Tropical Medicine and Public Health, 30: 735-740.

[9] Wali, J. P., Biswas, A., Handa, R., Aggarwal, P., Wig, N., and Dwivedi, S.N. (1999). Dengue haemorrhagic fever in adults: a prospective study of 110 cases. Tropical doctor, 29: 27-30.

[10] Back, A. T. and Lundkvist, A. (2013). Dengue viruses an overview. Infection Ecology and Epidemiology, The one Health Journal Vol 3.
[11] Ananda, A., Joel, N.K., William, L.G., and Harold, S.M. (2011). Dengue Virus Infection in Africa. Emergence Infectious Disease, 17(8): 1349-1354.

[12] Faneye, A., Idika, N., Motayo, B.O., Adesanmi, A., Afocha, E. (2013). Serological evidence of recent dengue virus infection among febrile children in a semi-arid zone. American Journal of Infectious Disease, 9: 7-10.

[13] Srinivas, R.M., S., Pavani K.M. Dass, M.A. Kareem and E.V. Vinayaraj, (2013). Seroprevalence of dengue virus in a tertiary care hospital, andhra Pradesh, South India. International Journal of Resource and Medicine, 1: 448450.

[14] Oladipo, E.K., Amanetu, C., Gbadero, T.A and Oloke, J.K. (2014). Detectable anti-dengue virus IgM antibodies among healthy individuals in Ogbomoso, Oyo state, Nigeria. American Journal of Infectious Disease, 10 (2):64-67.

[15] Baba, M.M., Sharon, M.F., Vorndam, A.V., Adeniji, J.A. and Diop, O. (2009). Dengue virus infections in patients suspected of malaria/thyphoid in Nigeria. Journal of American Science, 5: 129-134.

[16] Ukegbu, K.A. (2005). The National Year Book of Nigeria. $3^{\text {rd }}$ Edition. Gold Star Publication. Pp; 255-256.

[17] Sarmukaddam, S.S and Gerald, S.G. (2006).Validity of assumptions while determining sample size. Indian Journal of Community Medicine, 20-29.

[18] Yew, Y.W., Ye, T., Ang, L.W, Ng, L.C and Yap, G., James L., Chew, S.K., and Goh, K.T. (2009). Seroepidemiology of dengue virus infection among adults in Singapore. Annals of the Academy of Medicine. Singapore, 38: 667-675

[19] Gupta, E., L. Dar, P. Narang, V.K. Srivastava and S. Broor, (2005). Serodiagnosis of dengue during an outbreak at a tertiary care hospital in Delhi. Indian Journal of Medical Resources, 121: 36-38.

[20] Ukey, P.M., Bondade, S.A., Paunipagar, P.V., Powar and. Akulwar, S.L. (2010). Study of seroprevalence of dengue fever in central India. Indian Journal of Community Medicine, 3: 551-519.

[21] Kumar, A., Rao,C.R., Pandit, V., Shetty, S., C. Bamigalti and Samarasinghe, C.M. (2010). Clinical manifestations and trend of dengue cases admitted in a tertiary care hospital, Udupi, Karnataka. Indian Journal of Community Medicine, 35: 386-391.

\section{Author Profile}

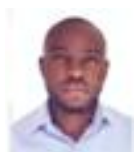

Bello Ayodele Olabode bagged a B.Sc and M.Sc. degrees in Microbiology from Ahmadu Bello University, Zaria, Kaduna, Nigeria in 2011 and 2016 respectively. He has developed the ardor for research in the area of virology which has driven him hitherto. Presently, he works as a scientific officer at the Federal Ministry of Environment in Nigeria. 